\title{
Relationships between cocoa mass percentage, surface color, free phenolic compounds content and antioxidant capacity of commercially available dark chocolate bars
}

\author{
Natalia Mikołajczak ${ }^{1} \cdot$ Małgorzata Tańska $^{1}$
}

Revised: 13 December 2019/Accepted: 26 December 2019/Published online: 27 November 2020

(C) The Author(s) 2020

\begin{abstract}
The aim of the study was to assess the relationships between cocoa mass percentage declared by producer and color, free phenolic compounds content and antioxidant capacity of chocolate bars. The research materials were commercially available 2 dessert (with 30 and $50 \%$ of cocoa mass) and 10 bitter chocolate bars (with $40-90 \%$ of cocoa mass). The scope of analysis included determining chocolate bars surface color using digital image analysis, content of free phenolic compounds (total, flavonoids and proanthocyanidins) using spectrophotometric methods and antioxidant capacity using the Cuprac method.

Based on the results, it was generally found that bitter chocolate bars were characterized by a darker color and a higher content of free phenolic compounds (252.38$703.13 \mathrm{mg} / 100 \mathrm{~g}$ ), including flavonoids (29.01-89.55 $\mathrm{mg} / 100 \mathrm{~g}$ ) and proanthocyanidins (52.23-224.47 mg/ $100 \mathrm{~g})$, compared to dessert chocolate bars (241.70, 38.58 and $58.99 \mathrm{mg} / 100 \mathrm{~g}$ on average, respectively). The study showed that the cocoa mass content in the chocolate bars was strongly positively correlated with the phenolic compounds content (in particular flavonoids) and the antioxidant capacity. On the other hand, these properties of the chocolate bars were less dependent on the surface color.
\end{abstract}

Keywords Chocolate bar - Color · Phenolic compounds · Antioxidant capacity $\cdot$ Cocoa mass content

Małgorzata Tańska

m.tanska@uwm.edu.pl

1 Department of Food Plant Chemistry and Processing, Faculty of Food Sciences, University of Warmia and Mazury, Plac Cieszyński 1, 10-726 Olsztyn, Poland

\section{Introduction}

In recent years, an increase in the incidence of diseases such as obesity and overweight has been observed among the population. It was proven that these diseases are caused by low physical activity and excessive consumption of sweets (high-energy products with low nutritional value). In a wide range of confectionery products there are also products that should not be excluded from the daily diet (subjected to moderate consumption) due to the presence of compounds that have a positive effect on the consumer's health, e.g. polyphenols, minerals, vitamins, and oligosaccharides (Nichols and Katiyar 2010). The example of this may be some chocolate products (Rogovska and Čukanová 2015).

According to the Directive (2000/36/WE) of the European Parliament and of the Council of 23 June 2000, chocolate is defined as 'the product obtained from cocoa products, and sugars, which contains not less than $35 \%$ total dry cocoa solids, including not less than $18 \%$ cocoa butter and no less than $14 \%$ dry non-fat cocoa mass'. This definition specifies that the cocoa mass may include cocoa liquor and/or cocoa powder and cocoa butter. Cocoa liquor and cocoa powder are characterized by a high content of phenolic compounds, which give chocolate a specific bitterness and astringency, as well as aroma and color (Elwers et al. 2009). In addition, the phenolic compounds are responsible for preventing the development of chronic noncommunicable diseases, i.a. cancers, diseases of the cardiovascular or nervous systems, increase resistance to coronary and heart disorders, prevent platelet aggregation (D'Archivio et al. 2007), stimulate hormone production, exert a positive effect on lipid metabolism, and are also involved in several other biological functions, such as skin protection (Nichols and Katiyar 2010). The dominant 
group of phenolic compounds in chocolate are flavonoids, in particular proanthocyanidins, catechins and quercetin, which may constitute up to $90 \%$ of the total phenolic compounds in chocolates with a high content of cocoa mass (Wollgast and Anklam 2000).

The main factor differentiating chocolate bars available on the market, is the content of cocoa mass, which must be declared by the producer on the packaging label (Yates 2009). In Poland, generally the highest cocoa mass content is found in bitter chocolate bars (usually above 75\%), less cocoa mass occurs in dessert chocolate bars (30-70\%), while in milk chocolate bars it is only $25 \%$. The products also differ in the content of sugar which the largest amounts are found in milk chocolate bars (over 50\%), lower amounts in dessert chocolate bars (40-50\%) and bitter chocolate bars (up to 40\%) (Jabłońska-Ryś 2012). In some countries, e.g. the USA, dark chocolate is a category of chocolate that includes semisweet and bittersweet chocolates. Typically, semisweet chocolate contains $35-45 \%$ cacao and is sweeter, while bittersweet chocolate usually contains at least 50\% cacao (NCA 2019). However, there are no legal regulations to distinguish chocolate bars between dark, bittersweet and semisweet.

The most popular among consumers are milk and filled chocolate bars. However, more and more often they also choose the dark chocolate bars (dessert and bitter) classified as functional food whose purpose is to improve consumer health and well-being (Rogovska and Čukanová 2015). There are a number of studies on the phenolic compounds in chocolate products (Belŝŝak et al. 2009; Albak and Tekin 2016; Gu et al. 2006; Pavlović et al. 2017), while information on the relation between the phenolic compounds content and the cocoa mass percentage in the products is rather scarce. Likewise, antioxidant capacity of chocolate was also previously studied (Miller et al. 2006; Baceral Leite et al. 2013; Brcanović et al. 2013; Laličić-Petronijević et al. 2016). However, most of the studies were focused on effect of process and storage conditions on chocolate composition (Albak and Tekin 2016; Laličić-Petronijević et al. 2016) and on comparison of various chocolate types (Miller et al. 2006; Belŝçak et al. 2009; Meng et al. 2009). Despite the valuable data on the variability among chocolate types in phenolic compounds content and antioxidant capacity, there is still a lack of knowledge on the relation between these properties of commercially available dark chocolate bars and information that is readily accessible to the consumer (color and cocoa mass content).

The aim of the research was to determine the impact of the minimum content of dry cocoa solids, declared by the producer, in dessert and bitter chocolate bars for color, free phenolic compounds content and antioxidant capacity. In addition, the occurrence of correlations between the analyzed properties was also evaluated.

\section{Material and methods}

\section{Chemicals and plant materials}

n-hexane, acetone, Folin-Ciocalteu reagent, anhydrous sodium carbonate, sodium nitrate, aluminum (III) chloride, sodium hydroxide, 1-butanol, copper chloride, neocuproin, ammonium acetate buffer and D-catechin were purchased from Sigma (Sigma-Aldrich, USA).

The research materials were 12 popular chocolate bars produced and bought in Poland, including 2 dessert chocolate bars and 10 bitter chocolate bars. All types of chocolate bars are available on the European food market (the same name and composition), and differed in the percentage content of dry cocoa solids in the product declared by the producer on the packaging label by the use of the term 'cocoa mass minimum ... \%' or 'cocoa content: minimum ...' '. Three packages of each type of chocolate bars from three different batches were purchased for the research. The research material characteristics including the type of chocolate bar, cocoa mass content and composition is presented in Table 1.

\section{Determination of surface color using digital image analysis (DIA)}

The color of chocolate bars was measured according to the methodology of Tańska et al. (2011) using a Nikon DXM1200 (Nikon Instruments, Melville, USA) charge coupled device (CCD). The color of chocolate bars was expressed in HSI color space.

\section{Preparation of chocolate bar extracts}

Preparation of extracts was carried out according to the method described by Meng et al. (2009). Defatting of chocolate bars $(5 \mathrm{~g})$ was carried out by twofold extraction with n-hexane $(10 \mathrm{~mL})$. A non-fat mass was dried under natural conditions, i.e. air at $20{ }^{\circ} \mathrm{C}$ for $24 \mathrm{~h}$. The extracts were prepared from the non-fat mass $(2 \mathrm{~g})$ using twofold extraction $(10 \mathrm{~mL})$ with $80 \%$ acetone, and then evaporated to dryness at temperature below $50{ }^{\circ} \mathrm{C}$ in a vacuum evaporator (Büchi, type R-210; Büchi Labortechnik, Flawil, Switzerland). The residue was dissolved in pure methanol $(25 \mathrm{~mL})$ and used to determine the content of free phenolic compounds and the antioxidant capacity in chocolate bars. 
Table 1 Chocolate bars (CB) used in the research and their color parameters measured by the image analysis

\begin{tabular}{|c|c|c|c|c|c|c|c|c|c|}
\hline \multirow[t]{2}{*}{$\begin{array}{l}\text { Chocolate } \\
\text { bar } \\
\text { symbol }\end{array}$} & \multirow[t]{2}{*}{$\begin{array}{l}\text { Chocolate } \\
\text { bar type }\end{array}$} & \multirow[t]{2}{*}{$\begin{array}{l}\text { Cocoa } \\
\text { mass/cocoa } \\
{[\%]^{*}}\end{array}$} & \multirow[t]{2}{*}{ Composition (declared on the packaging) } & \multicolumn{2}{|c|}{$\mathrm{H}$ (Hue) $\left[{ }^{\circ}\right]$} & \multicolumn{2}{|c|}{$\begin{array}{l}\text { S } \\
\text { (Saturation) } \\
{[\%]}\end{array}$} & \multicolumn{2}{|c|}{ I (Intensity) [\%] } \\
\hline & & & & $\bar{x}$ & $\delta$ & $\bar{x}$ & $\delta$ & $\bar{x}$ & $\delta$ \\
\hline CB1 & dessert & 30 (cocoa) & $\begin{array}{l}\text { Sugar, cocoa liquor, defatted milk powder, milk } \\
\text { fat, whey powder, emulsifier (from soybean } \\
\text { E322), flavor (vanillin) }\end{array}$ & $18.33^{\mathrm{d}}$ & 0.58 & $7.55^{\mathrm{c}}$ & 0.21 & $2.98^{\mathrm{e}}$ & 0.12 \\
\hline $\mathrm{CB} 2$ & bitter & $\begin{array}{l}40 \text { (cocoa } \\
\text { mass) }\end{array}$ & $\begin{array}{l}\text { Cocoa liquor, sugar, cocoa butter, emulsifier: } \\
\text { lecithin (from soy), natural vanilla extract }\end{array}$ & $21.67^{\mathrm{c}}$ & 1.53 & $8.46^{\mathrm{b}, \mathrm{c}}$ & 0.56 & $3.31^{\mathrm{b}, \mathrm{c}, \mathrm{d}, \mathrm{e}}$ & 0.13 \\
\hline CB3 & bitter & $\begin{array}{l}45 \text { (cocoa } \\
\text { mass) }\end{array}$ & $\begin{array}{l}\text { Sugar, cocoa liquor, plant fat (palm oil, shea), } \\
\text { cocoa butter, emulsifiers: lecithin (from soy) and } \\
\text { E476, flavor }\end{array}$ & $21.67^{\mathrm{c}}$ & 0.58 & $8.58^{\mathrm{b}}$ & 0.37 & $3.31^{\mathrm{b}, \mathrm{c}, \mathrm{d}, \mathrm{e}}$ & 0.15 \\
\hline CB4 & dessert & $\begin{array}{l}50 \text { (cocoa } \\
\text { mass) }\end{array}$ & $\begin{array}{l}\text { Sugar, cocoa liquor, reduced-fat cocoa, cocoa } \\
\text { butter, milk fat, emulsifiers (soya lecithin, E476), } \\
\text { salt, aroma }\end{array}$ & $20.67^{\mathrm{c}, \mathrm{d}}$ & 0.58 & $8.06^{\mathrm{b}, \mathrm{c}}$ & 0.17 & $3.15^{\mathrm{c}, \mathrm{d}, \mathrm{e}}$ & 0.19 \\
\hline CB5 & bitter & 51 (cocoa) & $\begin{array}{l}\text { Maltitol } 48 \% \text {, cocoa liquor, cocoa butter, inulin, } \\
\text { soy lecithin-emulsifier, vanillin-aroma }\end{array}$ & $19.33^{\mathrm{c}, \mathrm{d}}$ & 0.58 & $7.94^{\mathrm{b}, \mathrm{c}}$ & 0.28 & $3.12^{\mathrm{d}, \mathrm{e}}$ & 0.09 \\
\hline CB6 & bitter & $\begin{array}{l}55 \text { (cocoa } \\
\text { mass) }\end{array}$ & $\begin{array}{l}\text { Cocoa liquor, sugar, cocoa butter, reduced-fat } \\
\text { cocoa, emulsifier (soya lecithin) }\end{array}$ & $21.33^{\mathrm{c}}$ & 0.58 & $8.20^{\mathrm{b}, \mathrm{c}}$ & 0.22 & $3.23^{\mathrm{c}, \mathrm{d}, \mathrm{e}}$ & 0.18 \\
\hline CB7 & bitter & $\begin{array}{l}64 \text { (cocoa } \\
\text { mass) }\end{array}$ & $\begin{array}{l}\text { Cocoa liquor, sugar, reduced-fat cocoa, cocoa } \\
\text { butter, emulsifiers (soya lecithin and E476), } \\
\text { flavor }\end{array}$ & $21.00^{\mathrm{c}}$ & 0.00 & $8.22^{\mathrm{b}, \mathrm{c}}$ & 0.22 & $3.30^{\mathrm{b}, \mathrm{c}, \mathrm{d}, \mathrm{e}}$ & 0.23 \\
\hline CB8 & extra bitter & $\begin{array}{l}65 \text { (cocoa } \\
\text { mass) }\end{array}$ & $\begin{array}{l}\text { Cocoa liquor, sugar, cocoa butter, soy lecithin } \\
\text { (E322), aroma, whole milk powder }\end{array}$ & $24.67^{\mathrm{a}, \mathrm{b}}$ & 0.58 & $9.57^{\mathrm{a}}$ & 0.35 & $3.60^{\mathrm{b}, \mathrm{c}, \mathrm{d}}$ & 0.18 \\
\hline CB9 & bitter & $\begin{array}{l}70 \text { (cocoa } \\
\text { mass) }\end{array}$ & $\begin{array}{l}\text { Cocoa liquor, sugar, reduced-fat cocoa, cocoa } \\
\text { butter, emulsifier: lecithin (from soy), flavor }\end{array}$ & $21.33^{\mathrm{c}}$ & 1.53 & $8.38^{\mathrm{b}, \mathrm{c}}$ & 0.17 & $3.36^{\mathrm{b}, \mathrm{c}, \mathrm{d}, \mathrm{e}}$ & 0.25 \\
\hline CB 10 & bitter & $\begin{array}{l}72(\text { cocoa } \\
\text { mass })\end{array}$ & $\begin{array}{l}\text { Cocoa liquor, sugar, cocoa butter, emulsifier: } \\
\text { lecithin (soy), vanilla extract }\end{array}$ & $24.67^{\mathrm{a}, \mathrm{b}}$ & 0.58 & $9.77^{\mathrm{a}}$ & 0.11 & $3.74^{\mathrm{a}, \mathrm{b}}$ & 0.09 \\
\hline CB11 & bitter & $\begin{array}{l}76 \text { (cocoa } \\
\text { mass) }\end{array}$ & $\begin{array}{l}\text { Cocoa liquor, sugar, cocoa butter,, reduced-fat } \\
\text { cocoa, emulsifier (soya lecithin) }\end{array}$ & $24.33^{\mathrm{b}}$ & 0.58 & $9.62^{\mathrm{a}}$ & 0.33 & $3.64^{\mathrm{a}, \mathrm{b}, \mathrm{c}}$ & 0.20 \\
\hline CB12 & bitter & $\begin{array}{l}90 \text { (cocoa } \\
\text { mass) }\end{array}$ & $\begin{array}{l}\text { Cocoa liquor, reduced-fat cocoa, sugar, cocoa } \\
\text { butter, emulsifiers: lecithin (from soya) and } \\
\text { E476, flavor }\end{array}$ & $27.00^{\mathrm{a}}$ & 1.00 & $10.44^{\mathrm{a}}$ & 0.50 & $4.10^{\mathrm{a}}$ & 0.15 \\
\hline
\end{tabular}

${ }^{*}$ Minimum content of cocoa mass/cocoa (declared on the packaging); $\mathbf{x}$-average value; — standard deviation; a,b,c, ... - average values in columns with the same letter are not significantly different at $p \leq 0.05$

\section{Determination of free phenolic compounds content}

The content of total free phenolic compounds and free flavonoids were determined according to the method described by Meng et al. (2009). A color reaction with Folin-Ciocalteu reagent (total phenolic compounds content) and with 5\% aqueous sodium nitrate solution and $10 \%$ aqueous aluminum (III) solution (flavonoids content) were performed. Absorbance was measured at $720 \mathrm{~nm}$ (total free phenolic compounds) and $510 \mathrm{~nm}$ (free flavonoids) using a Unicam UV/Vis UV2 spectrophotometer (ATI Unicam, Cambridge, UK). Free proanthocyanidins content was determined according to the method described by Belŝscak et al. (2009). A reaction with 1-butanol- $\mathrm{HCl}$ reagent $(0.7 \mathrm{~g}$ of iron reagent $\left(\mathrm{FeCl}_{3} \times 7 \mathrm{H}_{2} \mathrm{O}\right)$ was added to $25 \mathrm{~mL}$ of concentrated $\mathrm{HCl}$ and then the solution was made up with a 1-butanol to a volume of $1000 \mathrm{~mL}$ ) in a boiling water bath for $2 \mathrm{~h}$ was performed. After the solution cooling down to room temperature, absorbance at $550 \mathrm{~nm}$ was measured using the Unicam UV/Vis UV2 spectrophotometer.

The total free phenolic compounds, free flavonoids and free proanthocyanidins contents were calculated based on the D-catechin calibration curve and expressed as mg D-catechin in $100 \mathrm{~g}$ of product.

\section{Determination of antioxidant capacity}

The antioxidant capacity of chocolate bars was determined using the Cuprac method described in the work of Apak et al. (2008). The extract $(0.2 \mathrm{~mL})$ was evaporated under vacuum in a Büchi rotary evaporator R-210 type and $1 \mathrm{~mL}$ of copper chloride, neocuproin, ammonium acetate buffer and $0.9 \mathrm{~mL}$ of distilled water were added. After $30 \mathrm{~min}$, the absorbance at $450 \mathrm{~nm}$ was measured using the Unicam UV/ 
Vis UV2 spectrophotometer. The antioxidant capacity was expressed as mM Trolox (TE) per $100 \mathrm{~g}$ of chocolate bar.

\section{Statistical analysis}

All analyzes were performed in triplicate and the obtained results were analyzed statistically using the Statistica 12.5 PL (StatSoft, Cracow, Poland). The differences between the chocolate bars was assessed using a variance analysis (ANOVA) at the significance level of $p \leq 0.05$ and Tukey's test. The intra-sample quality variation of the chocolate bars was assayed using principle component analysis (PCA) at $p \leq 0.05$ significance level.

\section{Results and discussion}

\section{Color of chocolate bars}

Bitter chocolate bars in comparison to dessert chocolate bars were characterized by higher values of individual components of the HSI color space (Table 1). The highest values of individual parameters $\mathrm{H}$ (Hue), $\mathrm{S}$ (Saturation) and I (Intensity) were found for bitter chocolate bar CB12 (cocoa mass content was at least 90\%), and amounted to $27.00^{\circ}, 10.44 \%$ and $4.10 \%$, respectively. Other bitter chocolate bars (with a minimum of $40-70 \%$ cocoa mass/cocoa in the product) were characterized by the values of these components in the ranges: 19.33-24.67 ${ }^{\circ}$, $7.94-9.77 \%$, and $3.12-3.74 \%$, respectively. The lowest values of the color components characterized dessert chocolate bar CB1 with the lowest cocoa content (about $30 \%$ in the product). The color of this chocolate bar, compared to the others, was more red $\left(\mathrm{H}=18.33^{\circ}\right)$ with a low saturation $(\mathrm{S}=7.55 \%)$ and intensity $(\mathrm{I}=2.98 \%)$. The greater share of redness in the color of chocolate bar with low cocoa mass content $(28.77 \%)$ compared to chocolate bars with its higher content (49.77\% and 64.27\%) were also indicated by López-Hernández and Quintero-Cerón (2016). However, there is a lack of literature data on the color parameters of chocolates with various cocoa mass content.

\section{Content of free phenolic compounds in chocolate bars}

The content of free phenolic compounds in studied chocolate bars is presented in Table 2. Bitter chocolate bars with a minimum of $40-90 \%$ content of cocoa mass/cocoa, were characterized by the high total content of free phenolic compounds, $252.38-703.13 \mathrm{mg} / 100 \mathrm{~g}$ of the product. Dessert chocolate bars with at least a $30 \%$ content of cocoa mass (CB1) contained slightly less free phenolic compounds, $139.03 \mathrm{mg} / 100 \mathrm{~g}$. Similar results of phenolic compounds in dark chocolate bars were presented by Pimentel et al. (2010). In their study, the chocolate bar with a $40 \%$ content of cocoa mass had the content of phenolic compounds of $499.00 \mathrm{mg} / 100 \mathrm{~g}$, while in chocolate bar with a $71 \%$ content of the cocoa mass it was almost 1.3fold higher. Baceral Leite et al. (2013) found that the content of phenolic compounds in dark chocolate bars (with a 70\% content of cocoa mass) made from cocoa beans grown in Brazil, is 154.6-91.1 mg in $100 \mathrm{~g}$ of product. Cooper et al. (2008) analyzing 46 plain dark chocolate bars (with the content of cocoa mass in the range of 34-100\%) purchased in Europe, estimated that the total content of phenolic compounds is in the range from 340 to $2,340 \mathrm{mg} / 100 \mathrm{~g}$.

The content of free flavonoids in the analyzed chocolate bars was significantly different $(p \leq 0.05)$ and was in the range of $24.41-89.55 \mathrm{mg} / 100 \mathrm{~g}$ of the product. The lowest amount was found in dessert chocolate bar CB1 (with at least a $30 \%$ content of cocoa), and the highest in bitter chocolate bar CB12 (with a minimum of $90 \%$ cocoa mass). The bitter chocolate bars (with a minimum content of cocoa mass/cocoa in the range of 40-90\%) were characterized by a free flavonoids content of $29.01-89.55 \mathrm{mg} /$ $100 \mathrm{~g}$, while the dessert chocolate bar with at least a $50 \%$ cocoa mass (CB4) contained $52.74 \mathrm{mg}$ flavonoids/100 g. Furthermore, it was found that the dessert chocolate bars had a higher percentage share of free flavonoids in the total content of free phenolic compounds compared to the bitter chocolate bars (15.31-17.56\% vs. 8.95-14.91\%). Meng et al. (2009) showed that the bitter chocolate bars contained $28.30 \mathrm{mg}$ flavonoids in $100 \mathrm{~g}$. However, in the cited work the content of cocoa mass in the products was not specified. In turn, Brcanović et al. (2013) reported that all flavonoids can constitute up to $37-70 \%$ of total phenolic compounds in dark chocolate bars.

The lowest content of free proanthocyanidins, 28.48 and $52.23 \mathrm{mg} / 100 \mathrm{~g}$, was found in chocolate bars CB1 (dessert) and CB2 (bitter). These products were also characterized by the lowest, declared by the producer, minimum content of cocoa mass/cocoa in the product, 30 and 40\%, respectively. Chocolate bars CB3 and CB4 (the minimum content of cocoa mass was $45 \%$ and $50 \%$, respectively) were characterized by a higher content of free proanthocyanidins, 84.48 and $89.49 \mathrm{mg} / 100 \mathrm{~g}$, respectively. Bitter chocolate bars with over $50 \%$ content of cocoa mass/cocoa were characterized by free proanthocyanidins in the range of 117.62 to $224.47 \mathrm{mg} / 100 \mathrm{~g}$. The highest content of these compounds was found in bitter chocolate bar CB11 $(76 \%$ of cocoa mass content). It was found that the free proanthocyanidins in the analyzed chocolate bars accounted for $20.48-42.74 \%$ of all free phenolic compounds. The dark 
Table 2 Content of free phenolic compounds and their antioxidant capacity in analyzed chocolate bars

\begin{tabular}{|c|c|c|c|c|c|c|c|c|c|c|}
\hline \multirow[t]{2}{*}{ Chocolate bar symbol } & \multicolumn{2}{|c|}{$\begin{array}{l}\text { Total free phenolic compounds } \\
{[\mathrm{mg} / 100 \mathrm{~g}]}\end{array}$} & \multicolumn{3}{|c|}{$\begin{array}{l}\text { Free flavonoids [mg/ } \\
100 \mathrm{~g}]\end{array}$} & \multicolumn{3}{|c|}{$\begin{array}{l}\text { Free proanthocyanidins }[\mathrm{mg} / \\
100 \mathrm{~g}]\end{array}$} & \multicolumn{2}{|c|}{$\begin{array}{l}\text { Antioxidant } \\
\text { capacity [mM TE/ } \\
100 \mathrm{~g}]\end{array}$} \\
\hline & $\bar{x}$ & $\delta$ & $\bar{x}$ & $\delta$ & {$[\%]^{*}$} & $\bar{x}$ & $\delta$ & {$[\%]^{*}$} & $\bar{x}$ & $\delta$ \\
\hline CB1 & $139.03^{\mathrm{j}}$ & 17.92 & $24.41^{\mathrm{g}}$ & 0.31 & 17.56 & $28.48^{\mathrm{i}}$ & 1.14 & 20.48 & $17.58^{\mathrm{e}, \mathrm{f}}$ & 0.73 \\
\hline CB2 & $252.38^{\mathrm{i}}$ & 6.73 & $37.63^{\mathrm{f}}$ & 3.75 & 14.91 & $52.23^{\mathrm{h}}$ & 4.00 & 20.69 & $15.30^{\mathrm{g}}$ & 0.07 \\
\hline CB3 & $321.63^{\mathrm{h}}$ & 14.84 & $29.01^{\mathrm{g}}$ & 0.16 & 9.02 & $84.48^{\mathrm{g}}$ & 0.61 & 26.27 & $16.18^{f, g}$ & 0.12 \\
\hline CB4 & $344.37^{\mathrm{g}, \mathrm{h}}$ & 13.65 & $52.74^{\mathrm{d}, \mathrm{e}}$ & 2.19 & 15.31 & $89.49^{\mathrm{g}}$ & 1.72 & 25.99 & $17.31^{\mathrm{e}, \mathrm{f}}$ & 0.83 \\
\hline CB5 & $355.94^{\mathrm{g}}$ & 9.39 & $37.21^{\mathrm{f}}$ & 2.66 & 10.45 & $148.55^{\mathrm{d}}$ & 5.55 & 41.74 & $18.07^{\mathrm{d}, \mathrm{e}}$ & 0.18 \\
\hline CB6 & $414.04^{\mathrm{f}}$ & 15.74 & $46.16^{\mathrm{e}}$ & 2.97 & 11.15 & $117.62^{\mathrm{f}}$ & 1.62 & 28.41 & $19.59^{\mathrm{b}, \mathrm{c}, \mathrm{d}}$ & 0.83 \\
\hline CB7 & $480.64^{\mathrm{e}}$ & 8.34 & $58.16^{\mathrm{c}, \mathrm{d}}$ & 0.16 & 12.10 & $205.44^{\mathrm{b}}$ & 7.27 & 42.74 & $19.31^{\mathrm{c}, \mathrm{d}}$ & 0.87 \\
\hline CB8 & $666.45^{\mathrm{b}}$ & 6.86 & $65.36^{\mathrm{b}, \mathrm{c}}$ & 2.81 & 9.81 & $212.08^{\mathrm{a}, \mathrm{b}}$ & 8.42 & 31.82 & $21.30^{\mathrm{b}}$ & 0.59 \\
\hline CB9 & $514.61^{\mathrm{d}}$ & 5.00 & $50.26^{\mathrm{e}}$ & 2.03 & 9.77 & $177.16^{\mathrm{c}}$ & 1.14 & 34.43 & $21.01^{\mathrm{b}, \mathrm{c}}$ & 0.26 \\
\hline CB10 & $703.13^{\mathrm{a}}$ & 7.33 & $62.92^{\mathrm{c}}$ & 1.40 & 8.95 & $223.71^{\mathrm{a}}$ & 8.74 & 31.82 & $21.26^{\mathrm{b}}$ & 0.10 \\
\hline CB11 & $588.48^{\mathrm{c}}$ & 8.92 & $71.43^{\mathrm{b}}$ & 5.01 & 12.14 & $224.47^{\mathrm{a}}$ & 9.85 & 38.14 & $20.31^{\mathrm{b}, \mathrm{c}}$ & 0.92 \\
\hline CB12 & $618.84^{\mathrm{c}}$ & 9.19 & $89.55^{\mathrm{a}}$ & 3.09 & 14.47 & $212.48^{\mathrm{a}, \mathrm{b}}$ & 8.19 & 34.34 & $28.79^{\mathrm{a}}$ & 0.28 \\
\hline
\end{tabular}

$[\%]^{*}-\%$ of the total content of free phenolic compounds, $\bar{x}-$ average value; $\delta$ - standard deviation;

$\mathrm{a}, \mathrm{b}, \mathrm{c}, \ldots$. - average values in columns with the same letter are not significantly different at $p \leq 0.05$

Symbols of chocolate bars are explained in Table 1

chocolate bars analyzed by Hii et al. (2009) contained proanthocyanidins in the amount of $278-410 \mathrm{mg} / 100 \mathrm{~g}$. However, surprisingly high content of proanthocyanidins was determined in the work of $\mathrm{Gu}$ et al. (2006). They found that in the dark chocolate bars the content of proanthocyanidins reached even $2,000 \mathrm{mg}$ in $100 \mathrm{~g}$ of the product.

In this study, it was observed that the content of total free phenolic compounds, flavonoids and proanthocyanidins strongly dependent on cocoa mass/cocoa in the product (correlation coefficient $(r)$ in the range of 0.901-0.924). Also the content of free proanthocyanidins was strongly positively correlated with the total free phenolic compounds $(r=0.943)$. Laličić-Petronijević et al. (2016) and Meng et al. (2009) also showed a strong correlation between total phenolic compounds content and the flavonoids content $(\mathrm{r}=0.998$ and 0.930 , respectively), which clearly indicates flavonoids as the main group of chocolate polyphenols. Lie et al. (2014) observed a negative correlation between the $\mathrm{L}^{*}, \mathrm{a}^{*}$ and $\mathrm{b}^{*}$ components and the total polyphenols content in the cocoa powder. According to the research of these authors, the darker color of the cocoa powder does not indicate higher total phenolic compounds content.

\section{Antioxidant capacity of chocolate bars}

All analyzed chocolate bars were characterized by high and significantly differentiated $(p \leq 0.05)$ antioxidant capacity (Table 2). Dessert chocolate bars were characterized by antioxidant capacity in the range of 17.31-17.58 mM TE/ $100 \mathrm{~g}$, while bitter chocolate bars in the range of 15.30-28.79 mM TE/100 g. The highest antioxidant capacity was found in bitter chocolate bars with a high content of cocoa mass (minimum 65-90\%), and the lowest in bitter chocolate bars $\mathrm{CB} 2$ and $\mathrm{CB} 3$, in which the minimum content of cocoa mass was 40 and $45 \%$, respectively. Similarly, in research conducted by Meng et al. (2009), dark chocolate bars showed the highest antioxidant capacity, followed by milk and white chocolate bars.

Taking into account relationships between analyzed parameters of chocolate bars, it was found that the antioxidant capacity correlated mostly positively with the content of cocoa mass/cocoa in the product $(r=0.856)$, the content of free flavonoids $(r=0.833)$ and individual components of the HSI color space ( $r$ in the range of 0.785-0.797). Laličić-Petronijević et al. (2016) reported that the antioxidant capacity of chocolate bars determined using various assays is strongly correlated with the content of proanthocyanidins $(\mathrm{r} \geq 0.966)$ and flavonoids ( $\mathrm{r}$ $\geq 0.948$ ). In turn, Brcanović et al. (2013) indicated proanthocyanidins as the main phenolic compounds determining the antioxidant capacity of chocolate bars.

\section{PCA model for chocolate bars}

The PCA analysis revealed variations among studied chocolate bars (Fig. 1). According to the first two principal components (PC1 and PC2) that accounted for $92.59 \%$ of 


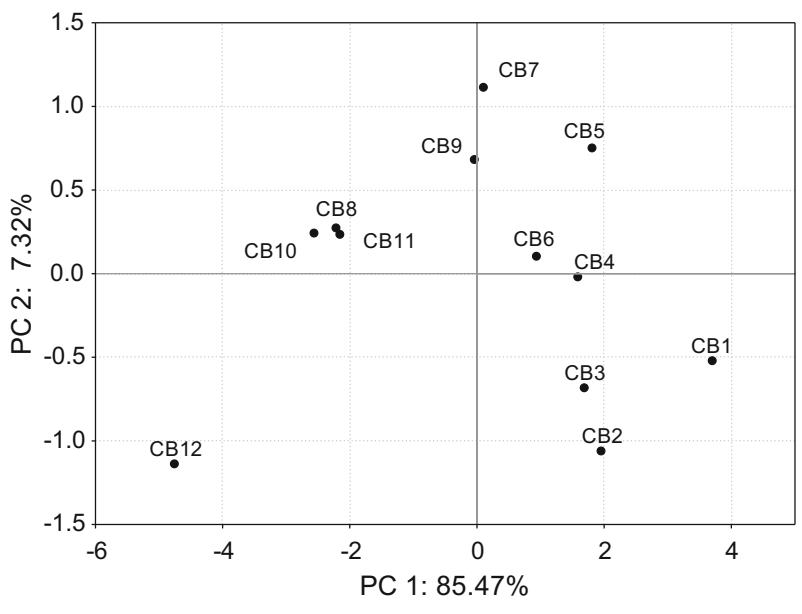

Fig. 1 Projection of the studied chocolate bars in the space defined by the first two principal components (PC1 and $\mathrm{PC} 2$ ) based on the determined parameters. Symbols of chocolate bars are explained in Table 1

total variance, the chocolate bar with the highest cocoa mass content (CB12) clearly differed from the others. The product characterized by the most red, saturated and intense color, and at the same was the most abundant in flavonoids. In turn, the chocolate bars with $30-45 \%$ of cocoa mass (CB1-CB3) contained the lowest amount of all polyphenols from all analyzed chocolate bars (less than $320.00 \mathrm{mg} / 100 \mathrm{~g}$ ), what also resulted in visible separation of these samples on PCA scores plot.

\section{Conclusions}

In the present study the minimum content of dry cocoa solids in chocolate bars, which was declared on the packaging label, have been taken into account. Based on the value of correlation coefficients, it can be concluded that the content of cocoa mass and the color of chocolate bars may be preliminary information for the consumer on the content of phenolic compounds, mainly flavonoids, in the product. The obtained results confirm that chocolate bars, especially with high cocoa mass content, are rich in free phenolic compounds, including flavonoids and proanthocyanidins. However, there are deviations from these dependencies, which may result from partially overlapping ranges of cocoa mass content typical for bitter and dessert chocolate bars. Furthermore, the producers provide a minimum, not exact, content of cocoa mass in chocolate bars. Also the products may contain not typical components, e.g. milk powder in bitter chocolate bars and plant fat (palm, shea) in a larger amount than cocoa butter in dark chocolate. These ingredients can also affect the physicochemical characteristics of chocolate bars.

\section{Compliance with Ethical Standards}

Conflict of Interest The authors declare no conflict of interest. This article does not contain any studies with human or animal subjects.

Open Access This article is licensed under a Creative Commons Attribution 4.0 International License, which permits use, sharing, adaptation, distribution and reproduction in any medium or format, as long as you give appropriate credit to the original author(s) and the source, provide a link to the Creative Commons licence, and indicate if changes were made. The images or other third party material in this article are included in the article's Creative Commons licence, unless indicated otherwise in a credit line to the material. If material is not included in the article's Creative Commons licence and your intended use is not permitted by statutory regulation or exceeds the permitted use, you will need to obtain permission directly from the copyright holder. To view a copy of this licence, visit http://creativecommons. org/licenses/by/4.0/.

\section{References}

Albak F, Tekin AR (2016) Variation of total aroma and polyphenol content of dark chocolate during three phase of conching. J Food Sci Technol 53(1):848-855. https://doi.org/10.1007/s13197-0152036-4

Apak R, Güclü L, Özyürek M, Celik SE (2008) Mechanism of antioxidant capacity assays and the CUPRAC (cupric ion reducing antioxidant capacity) assay. Microchim Acta 160(4):413-419. https://doi.org/10.1007/s00604-007-0777-0

Baceral Leite P, Fonseca ML, França Opretzka LC, Soares SE, Da Silva BE (2013) Phenolic compounds, methylxanthines and antioxidant activity in cocoa mass and chocolates produced from "witch broom disease" resistant and non resistant cocoa cultivars. Ciênc Agrotec Lavras 37(3):244-250. https://doi.org/ 10.1590/S1413-70542013000300007

Belŝŝak A, Komes D, Horžić D, Ganić KK, Karlović D (2009) Comparative study of commercially available cocoa products in terms of their bioactive composition. Food Res Int 42(5-6):707-716. https://doi.org/10.1016/j.foodres.2009.02.018

Brcanović JM, Pavlović AN, Mitić SS, Stojanović GS, Manojlović DD, Kaličanin BM, Veljković JN (2013) Cyclic voltammetric determination of antioxidant capacity of cocoa powder, dark chocolate and milk chocolate samples: correlation with spectrophotometric assays and individual phenolic compounds. Food Technol Biotechnol 51(4):460-470. https://doi.org/10.17221/ 265/2016-CJFS

Cooper KA, Campos-Giménez E, Jiménez Alvarez D, Rytz A, Nagy K, Williamson G (2008) Predictive relationship between polyphenol and nonfat cocoa solids content of chocolate. J Agric Food Chem 56(1):260-265. https://doi.org/10.1021/ jf072153c

D’Archivio M, Filesi C, Di Benedetto R, Gargiulo R, Giovannini C, Masella R (2007) Polyphenols, dietary sources and bioavailability. Ann I Super Sanita 43(4):348-361

Directive (2000/36/WE) of the European Parliament and of the Council of 23 June 2000 relating to cocoa and chocolate products intended for human consumption, Dz.U.L197, 3.8:19

Elwers S, Zambrano A, Rohsius C, Lieberei R (2009) Differences between the content of phenolic compounds in Criollo, Forastero and Trinitario cocoa seed (Theobroma cacao L.). Eur Food Res Technol 229(6):937-948. https://doi.org/10.1007/s00217-009$1132-\mathrm{y}$ 
Gu L, House SE, Wu X, Ou B, Prior RL (2006) Procyanidin and catechin contents and antioxidant capacity of cocoa and chocolate products. J Agric Food Chem 54(11):4057-4061. https://doi.org/10.1021/jf060360r

Hii CL, Law CL, Misnawi SS, Cloke M (2009) Polyphenols in cocoa (Theobroma cocao L.). As J Food Ag-Ind 2(04):702-722

Jabłońska-Ryś E (2012) Zawartość polifenoli w czekoladach. Nauka Przyr Technol 6(2):1-11 ((in Polish))

Laličić-Petronijević J, Komes D, Gorjanović S, Belščak-Cvitanović A, Pezo L, Pastor F, Ostojić A, Popov-Raljić J, Sužnjević D (2016) Chocolate antioxidant capacity during storage. Food Technol Biotechnol 54(1):13-20. https://doi.org/10.17113/ftb. 54.01.16.4014

Lie Y, Zhu S, Feng Y, Xu F, Ma J, Zhong F (2014) Influence of alkalization treatment on the color quality and the total phenolic and anthocyanin contents in cocoa powder. Food Sci Biotechnol 23(1):59-63. https://doi.org/10.1007/s10068-014-0008-5

López-Hernández M, Quintero-Cerón JP (2016) Characterization of chocolate added with unrefined cane sugar by tristimulus colorimetry. Agron Colomb Sup 1(1):815-818

Meng CC, Jalil AM, Ismail A (2009) Phenolic and theobromine contents of commercial dark, milk and white chocolates on the Malaysian market. Molecules 14(1):200-209. https://doi.org/10. 3390/molecules 14010200

Miller KB, Stuart DA, Smith NL, Lee CY, McHale NL, Flanagan JA, Ou B, Hurst W (2006) Antioxidant activity and polyphenol and procyanidin contents of selected commercially available cocoacontaining and chocolate products in the United States. J Agric Food Chem 54(11):4062-4068. https://doi.org/10.1021/ jf060290o

Nichols JA, Katiyar SK (2010) Skin photoprotection by natural polyphenols: anti-inflammatory, antioxidant and DNA repair mechanisms. Arch Dermatol Res 302(2):71-83. https://doi.org/ 10.1007/s00403-009-1001-3
NCA (2019) Kinds of Chocolate. National Confectioners Association. https://www.candyusa.com/story-of-chocolate/what-is-choco late/kinds-of-chocolate/

Pavlović AN, Mrmošanin JM, Krstić JN, Mitić SS, Tošić SB, Mitić MN, Arsić BB, Micić RJ (2017) Effect of storage temperature on the decay of catechins and procyanidins in dark chocolate. Czech J Food Sci 35(4):360-366. https://doi.org/10.17221/265/2016CJFS

Pimentel FA, Nitzke JA, Klipel CB, Vogt de Jong E (2010) Chocolate and red wine - A comparison between flavonoids content. Food Chem 120:109-112. https://doi.org/10.1016/j.foodchem.2009. 09.078

Rogovska V, Čukanová M (2015) Chocolate as a functional food. In: Wallner $\mathbf{J}$ (ed) Competitiveness of the food producing enterprises, EDAMBA 2015: International Scientific Conference for Doctoral Students and Post-Doctoral Scholars, 1st edn. Ekonom, Bratislava, pp 735-747

Tańska M, Konopka I, Korzeniewska E, Rotkiewicz D (2011) Colour of rapeseed (Brassica napus) surface and contamination by fungi during storage of dry and wet seed. Int J Food Sci Technol 46(11):2265-2273. https://doi.org/10.1111/j.1365-2621.2011. 02745.x

Wollgast J, Anklam E (2000) Polyphenols in chocolate: is there a contribution to human health? Food Res Int 33(6):449-459. https://doi.org/10.1016/S0963-9969(00)00069-7

Yates P (2009) Formulation of chocolate for industrial applications. In: Talbot G (ed) Science and technology of enrobed and filled chocolate, confectionery and bakery products, 1st edn. Woodhead, Cambridge, pp 29-52

Publisher's Note Springer Nature remains neutral with regard to jurisdictional claims in published maps and institutional affiliations. 